

SMITHSONIAN INSTITUTION

U. S. NATIONAL MUSEUM

\title{
REVISION OF THE FISHES OF THE FAMILY MICRODES- MIDAE, WITH DESCRIPTION OF A NEW SPECIES ${ }^{1}$
}

By Earl D. Reid

Division of Fishes, United States National Museum

GÜNTher described and figured the genotype of Microdesmus (dipus), a specimen $4 \frac{1}{2}$ inches in length, collected on the Pacific coast of Panama by Capt. J. M. Dow. This example, now in the British Museum, remained the sole representative of the genus until the appearance of $M$. retropinnis Jordan and Gilbert, based on an example nearly 4 inches in length, taken in a rocky tide pool at Panama, early in the spring of 1881 , by Dr. Charles H. Gilbert. The genus Cerdale appeared in the same paper following the description of $M$. retropinnis but was disassociated from Microdesmus on characters that at that time seemed sound when one considers the limited material at hand. Weymouth, in 1911, described an extremely elongate form, creating for it the genus Leptocerdale, the first of the group to be recorded from the Atlantic. This specimen, $210 \mathrm{~mm}$ long, was taken June 11, 1906, at the outlet of Calcasien Lake, near Cameron, La., by H. M. Spaulding. In 1927 Chabanaud described the first species to be recorded from the Old World, under the name Leptocerdale aethiopicum. The type, $51 \mathrm{~mm}$ in length, was taken at Malimba Bay, Kwele-Kwele Island, in Douala Bay, Cameroons. In 1928 Meek and Hildebrand described and figured three new species of Microdesmus, overlooking a fourth undescribed form from material

\footnotetext{
1 Since this paper went to press, an additional species, Cerdale bulineatus Clark (Proc. California Acad. Sci., ser. 4 , vol. 21 , no. 29 , p. 394 , Aug. 12 , 1936), apparently referable to the Microdesmidae, has been described from Indefatigable Island.
} 
collected at Chame Point, Panama, by Robert Tweedlie. Cerdale floridana Longley was described in 1934 from several specimens collected at Tortugas, Fla., in water not exceeding 10 fathoms in depth. Five of these specimens are deposited in the National Museum collections, and they represent the smallest species of the genus so far reported.

Unfortunately, the types of Cerdale ionthas Jordan and Gilbert and of Microdesmus retropinnis Jordan and Gilbert were never received at the National Museum, although they are recorded as having been deposited there. M. retropinnis is represented in the National Museum collections by two examples, 85 and $99 \mathrm{~mm}$ in length, collected in rocky tide pools at Chame Point, Panama. Of Cerdale ionthas we have two specimens from Panama, one collected by Gilbert and the other by Tweedlie.

The National Museum received a specimen of Microdesmus on June 10, 1935, from Prof. Manuel Valerio, formerly director, Museo Nacional, San José, Costa Rica. It was labeled "S. Lucas", and I assume that it was collected on the Pacific coast of the Isthmus by the donor. This specimen, $59 \mathrm{~mm}$ in standard length, proved to be Microdesmus dipus Günther, the second record of this rare fish. Comparison of this specimen with the "Microdesmus dipus" of Meek and Hildebrand shows that the latter was erroneously identified, a fact not wholly unsuspected by these authors.

Careful study of the material before me shows conclusively that Cerdale Jordan and Gilbert and Leptocerdale Weymouth are without generic value, merely representing extreme specific variations within the genus Microdesmus. Since Cerdale falls as a synonym of Microdesmus, the family name Cerdalidae must be changed to Microdesmidae.

Our material shows conclusively that the characters of the branchial openings, chiefly relied upon for differentiating between Cerdale Jordan and Gilbert, Leptocerdale Weymouth, and Microdesmus Günther, are without generic value, being perfectly graduated between $M$. floridanus on the one hand and $M$. longipinnis on the other. The point of origin of the dorsal fin is likewise specific, $M$. aethiopicus being intermediate between $M$. ionthas and $M$. retropinnis. The genotype, $M$. dipus, is intermediate between $M$. ionthas and $M$. longipinnis in all important external characters as well as the number of vertebrae.

It is evident from the wide distribution of the genus that only a very small percentage of the species of Microdesmus are known at the present time. The only species of which we have a fair series is the one having the greatest number of rays in the vertical fins, and it is 
reasonable to assume that this species represents the maximum in variation of the fin-ray counts of the known species. In this series of 30 specimens the fin-ray counts are as follows, the figure in parentheses representing the number of specimens:

Dorsal fin: 73 (3), 74 (4), 75 (6), 76 (4), 77 (9), 78 (4). Anal fin: 58 (9), 59 (10), 60 (5), 61 (5). Counts of body myomeres: 19 (2), 20 (19), 21 (9). Counts of caudal myomeres: 38 (1), 39 (5), 40 (15), $41(8), 42(1)$.

The myomeric impressions are counted from the base of the pectoral fin, along flank to above vent, and to the hypural. Vertebrae counts are from X-ray photographs.

It was found impracticable to separate the counts of the vertical fin supports into spinous and soft ray sections, the difference between the anterior and posterior portions being so gradual that no definite point of differentiation can be reliably fixed.

I am indebted to Dr. George S. Myers, formerly assistant curator of fishes, United States National Museum, for valuable assistance in the preparation of the manuscript and key. The vertebral counts were made possible by courtesy of the authorities of the United States Naval Hospital and of Dr. Dirk Meindert te Groen, Lieutenant (M. C.), U. S. Navy, in charge of X-ray.

\section{Genus MICRODESMUS Günther}

Microdesmus Günther, Proc. Zool. Soc. London, 1864, p. 26. (Type, Microdesmus dipus Günther.)

Cerdale Jordan and Gilbert, Bull. U. S. Fish Comm., vol. 1, p. 332, 1881 (1882). (Type, Cerdale ionthas Jordan and Gilbert.)

Leptocerdale Wеумоттн, Proc. U. S. Nat. Mus., vol. 38, p. 142, 1910. (Type, Leptocerdale longipinnis Weymouth.)

Body moderate or very elongate, slender, somewhat compressed. Vertebrae moderate or numerous. Head short, snout obtuse, usually with swollen longitudinal ridges or muscular folds. Mouth small, not protractile, more or less oblique. Lips thick, with pronounced flanges. Chin strongly projecting in the anterior profile, usually with longitudinal ridges. Vertical fins long and low, united with the caudal by membrane. Gill openings restricted laterally, oblique, broadly joined to the isthmus. Ventral fins closely approximated, rays I-3. Teeth in the jaws in two irregular series, absent on vomer and palatines. No cirri or filaments. Lateral line absent.

Small anguilliform fishes of tropical shores and tidepools, living in burrows in sand or mud. 
KEY TO THE SPECIES OF MICRODESMUS

$a^{1}$. Vent situated in posterior half of standard length.

$b^{1}$. Upper angle of gill opening opposite lower pectoral rays.

$c^{1}$. Dorsal 41 to 44 ; anal 26 to 29 ionthas

$c^{2}$. Dorsal 45 to 47 ; anal 30 to 33

floridanus

$b^{2}$. Upper angle of gill opening opposite or above base of middle pectoral rays.

$d^{1}$. Origin of dorsal fin less than one head-length behind head.

$e^{1}$. Dorsal fin supports 47; anal fin supports 26 to 30 ; origin of dorsal fin about two-thirds head-length behind tip of appressed pectoral

aethiopicus

$e^{2}$. Dorsal fin supports 55 or more; anal fin supports 34 or more; origin of dorsal above or before tip of appressed pectoral.

$f^{1}$. Dorsal fin supports 55; anal fin supports 34_...........dipus

$f^{2}$. Dorsal fin supports 69 ; anal fin supports $43 \ldots \ldots \ldots$.

$d^{2}$. Origin of dorsal fin at least two head-lengths behind

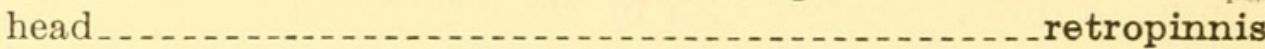

$a^{2}$. Vent situated in anterior half of standard length.

$b^{1}$. Body moderately elongate, head contained 8 to 13 times in standard length; depth of body 10 to 20 .

$c^{1}$. Predorsal region contained 5 to 7 times in standard length; dorsal 55 to 67 ; anal 38 to 48 .

$d^{1}$. Depth about 20, preventral 10; dorsal 55; anal 38......hildebrandi

$d^{2}$. Depth 10 to 11 , dorsal 67; anal 48............... intermedius

$c^{2}$. Predorsal 8 to 9 times in standard length, dorsal 76 ; anal 58

multiradiatus

$b^{2}$. Body very elongate, head contained about 15 to 17 times in

standard length; depth 28 to $34 \ldots \ldots$ longipinnis

MUCRODESMUS IONTHAS (Jordan and Gilbert)

Figure $9, b$; Figure 10, $a$; Plate 2, Figure 1

Cerdale ionthas Jordan and Gilbert, Bull. U. S. Fish Comm., vol. 1, p. 332, 1881 (1882) (Panama Bay).-Jordan and Evermann, U. S. Nat. Mus. Bull. 47, pt. 3, p. 2449, 1898 (Panama).-Gilbert and Starks, Mem. California Acad. Sci., vol. 4, p. 196, pl. 31, fig. 58, 1904 (Panama Bay).

Body comparatively short, of nearly equal depth throughout, strongly compressed posteriorly. Lower jaw strongly projecting, with a small fleshy lump at the symphysis. Head 7.2 in standard length; depth 8.5 to 9.2 ; predorsal 4.9 to 5.1 ; preanal 1.6 to 1.9 ; caudal 2.2 to 2.4 ; preventral 7.2 ; base of ventrals to vent 2.6 to 2.9 ; snout 5.4 to 5.9 in head, measured to upper end of gill opening; interorbital 4.2 to 4.3 . Dorsal 41 to 44 ; anal 26 to 29 ; pectoral 12 ; ventral I-3. Eye comparatively large, lateral, about equal to length of snout; mouth small, oblique, not quite reaching to anterior edge of eye; lips not notably fleshy, the lateral flanges small and inconspicuous; longitudinal ridges of snout and lower jaw well developed. Teeth very small, close-set, in two irregular series in the jaws, vomer and palatines toothless. Gill openings restricted laterally, the upper end in front of lower pectoral ray, the aperture extending obliquely 

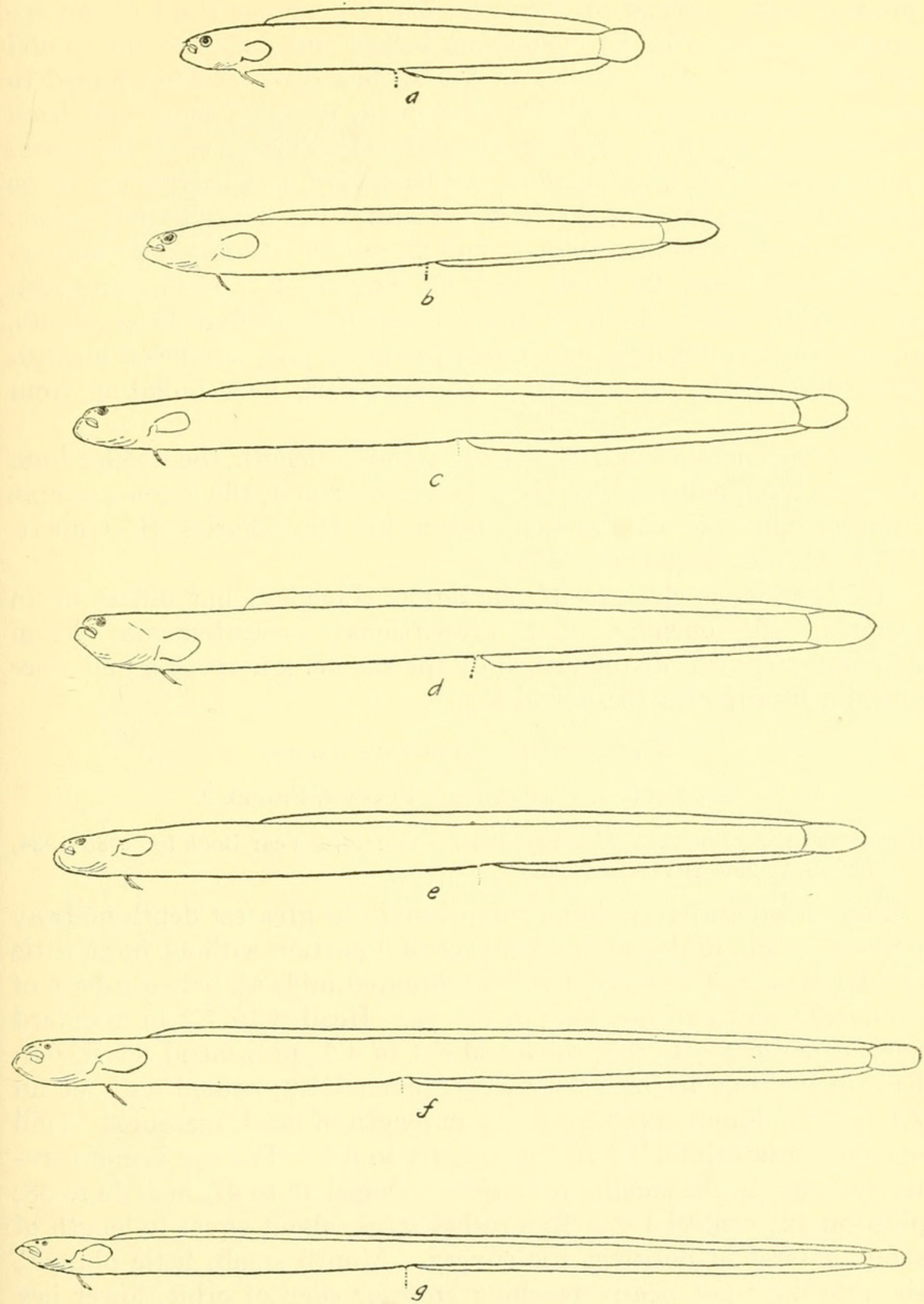

FIGURE 9.- $a$, Microdesmus floridanus (Longley), outline drawing of the type, natural size; $b, M$. ionthas (Jordan and Gilbart), outline drawing, natural size; c, $M$. dipus Günther, outline drawing, $\times 1.5$; $d, M$. aethiopicus (Chabanaud), outline drawing of the author's figure, natural size; e, M. retropinnis Jordan and Gilbert, outline drawing, natural size; $f, M$. hildebrandi, new species, outline drawing of the type, natural size; $g, M$. longipinnis (Weymouth), outline drawing of paratype, one-half natural size. 
downward and forward about as in related species to a point well below and before the base of the fin, the opening about half width of the pectoral base. Origin of dorsal fin above posterior third of the appressed pectoral, the fin of medium height and joined to the caudal by membrane. Anal similar to dorsal, but much shorter, joined to caudal by membrane. Seales very small, covering body and head except snout and lower jaw, the rows of seales at the base of the dorsal and anal fins diverging outward and backward on a narrow flat plane the full length of the fin base. Scales with 33 radiating striae. Myomeres conspicuous, 19 body and 22 caudal $=41$ muscular impressions. Vertebrae, 20 body and 22 caudal $=42$. Color brownish above, pale below, the head and sides with small dark-brown spots, these forming faint dark bars under the lower jaw, the dorsal fin with faint dark spots, an indication of faint dark bars radiating from the eye.

Two specimens, 51 and $65.5 \mathrm{~mm}$ in standard length, the smaller from Panama Reef, collected by Meek and Hildebrand; the larger example from a tide pool at Panama, taken by Dr. Charles H. Gilbert. U.S.N.M. nos. 50396 and 82677.

This species is close to $M$. floridanus (Longley) but differs in fin formula, gill opening, and proportional measurements. From $M$. aethiopicus it is distinguished by the smaller gill opening and more anterior insertion of the dorsal fin.

\section{MICRODESMUS FLORIDANUS (Longley)}

Figure 9, $a$; Figure 10, $b$; Plate 2, Figure 2

Cerdale floridana Longley, Carnegie Inst. Washington Year Book for 1933-1934, no. 33 , p. 259, 1934 (Tortugas).

Body comparatively short, compressed, the greatest depth midway between origin of dorsal and vent; caudal portion without fin, a little shorter than rest of body, the vent situated midway between base of caudal fin and anterior margin of eye. Head 6 to 7.2 in standard length; depth 8.5 to 9.5 ; predorsal 4.3 to 4.9 ; preventral 5.9 to 6.8 ; base of ventrals to vent 2.6 to 2.9 ; preanal 1.9 ; caudal without fin 2.1 to 2.2 . Snout short 5.5 to 7.7 in length of head, measured to gill opening; interorbital 4.7 to 6.4 ; eye 4.1 to 6.0 . The eye is comparatively larger in the smaller examples. Dorsal 45 to 47 ; anal 30 to 33 ; pectoral 12; ventral I-3. Eye rather large, about equal to length of snout, lateral in position, iris silvery. Mouth small, little oblique, the maxillary not nearly reaching anterior edge of orbit; lower jaw projecting, with a small fleshy conical tip forming the anterior profile of the head. Lips small, restricted laterally, the free folds not passing around the mouth anteriorly. Snout and lower jaw with longitudinal ridges and muscular folds, though not so well developed as in related 



Figure 10.- $a$, Microdesmus ionthas (Jordan and Gilbert), detailed enlargement of head, $\times 4 ; b, M$. floridanus (Longley), detailed enlargement of head of type, $\times 4 ; c, M$. dipus Günther, detailed enlargement of head, $\times 5$. 
species. Anterior nostril in a very minute pore at the oral end of the outer frontal ridge; posterior nostril close above and before eye. Teeth very small, apparently in two irregular series in the jaws, vomer and palatines toothless. Gill openings very small, oblique, close in front of the lower pectoral ray, the length of the aperture equal to the diameter of the pupil. Body and head, except snout and lower jaw, covered with minute nonimbricate scales imbedded in the skin; rows of scales of the dorsal region following the direction of the myomeric impressions. Scales with 30 radiating striae. Myomeres evident, 20 body and 23 caudal $=43$ muscular impressions. Vertebrae, 20 body and 24 caudal $=44$. Origin of dorsal above posterior third of the appressed pectoral, the fin long and moderately high, attached to caudal fin at base by membrane; anal similar but much shorter, attached to caudal by membrane. Ventrals small, close together, situated directly below pectoral base. Color pale straw, fins immaculate, back and sides above with small dark-brown freckles evenly and uniformly distributed, lower flank and belly lighter straw.

Five examples from Tortugas, Fla. Standard length 38.4 to 60 mm, of which the type, U.S.N.M. no. 102050, is the largest. Collector, Dr. W. H. Longley.

This species is distinguished from $M$. ionthas (Jordan and Gilbert) by the smaller gill openings, number of rays in the vertical fins, and proportional measurements. From M. aethiopicus (Chabanaud) it is distinguished by the more anterior insertion of the dorsal fin and by the much smaller gill opening.

\section{MICRODESMUS AETHIOPICUS (Chabanaud)}

\section{Figure $9, d$}

Leptocerdale aethiopicum Chabanadd, Bull. Mus. Hist. Nat., vol. 33, no. 3, pp. 230-234, 1927; Bull. Soc. Zool. France, vol. 53, pp. 279-285, figs. 1-4, 1928 (Cameroons).

Body elongate, compressed, the caudal portion without fin shorter than rest of body, the vent situated about midway between the occiput and base of caudal fin. Head 10 percent of total length; depth 6.4 ; predorsal 21; preanal 54; preorbital from anterior border of eye to tip of mandible 25 percent of length of head; diameter of eye 12 ; interorbital 8; length of pectoral 50; ventral 46; caudal fin 100. The diameter of the eye is contained slightly more than twice in the distance between the eye and the tip of the lower jaw. Thickness of the body at the base of the pectoral fins 83 percent of the depth of the body at the same point; depth at base of caudal fin 41 . Dorsal 47; anal 26; pectoral 12 ; ventrals 4 . Origin of the dorsal fin about one head-length behind the occiput, or at a point behind the tip of the snout equal to half the length of the base of the anal fin. Vertical 
fins joined to caudal by membrane. Ventral fins small, close together, situated opposite base of the pectorals. Gill openings small, restricted laterally, the upper angle attached opposite the base of the third pectoral ray, the opening extending obliquely downward and forward at an angle of $45^{\circ}$ with the axis of the body to a point below and in front of the lower pectoral ray, the aperture about equal to width of the pectoral base. Body and head, except snout and lower jaw, covered with minute nonimbricate scales imbedded in the skin. Color light brown, the upper surface with small dark spots and reticulations, the spots forming dark bands on the body that extend well down on the flank following the course of the myomeric impressions.

Type taken at Malimba Bay, Kwele-Kwele Island, in Douala Bay, Cameroons. Total length $51 \mathrm{~mm}$. Paratype from near same locality.

This species differs from $M$. ionthas (Jordan and Gilbert) and from $M$. floridanus (Longley) in the more posterior insertion of the dorsal fin and larger gill openings.

\section{MICRODESMUS DIPUS Günther}

Figure 9, $c$; Figure 10, $c$; Plate 2, Figure 3

Microdesmus dipus Günther, Proc. Zool. Soc. London, 1864, p. 26, pl. 3, fig. 2 (Panama).-Lockington, Proc. Acad. Nat. Sci. Philadelphia, 1881, p. 114 (La Paz, Lower California).-Jordan and Evermann, U. S. Nat. Mus. Bull. 47, pt. 3, p. 2450, 1898 (Panama).-Gilbert and Starks, Mem. California Acad. Sci., vol. 4, p. 195, 1904 (name only).

Body comparatively short, of about equal depth throughout, somewhat compressed posteriorly. Lower jaw projecting, with a small inconspicuous fleshy lump at the symphysis. Caudal portion of body little shorter than rest of body, the vent about midway between base of caudal fin and posterior border of eye, or slightly nearer base of fin. Head 9.2 in standard length; depth 14.7; predorsal 6.3 ; preanal 1.8; caudal without fin 2.3 ; preventral 9.3 ; base of ventrals to vent 2.2 ; snout 6.4 in head measured to upper end of gill opening; interorbital 8. Dorsal 55, anal 34, pectoral 12, ventral I-3. Eye small but larger than in related species, about equal to length of snout, high and lateral. Mouth small, little oblique, the gape not reaching anterior border of the eye. Lower jaw and snout with well-defined longitudinal ridges. Lips thin, with small flanges laterally, the lower slightly larger; anterior nostril a small round pore at the oral end of the frontal longitudinal ridges; posterior nostril porelike, above and before eye. Teeth minute, even, close-set, in two irregular series in the jaws; vomer and palatines toothless. Gill openings restricted laterally, extending from base of the fourth pectoral ray obliquely downward and forward to a point in front of lower ray of fin, the length of the opening about equal to the width

$78934-36-2$ 
of the pectoral base. Body covered with minute scales imbedded in the skin, snout and lower jaw naked; a flat band of diverging scales follows the base of the dorsal and anal fins throughout their length, those of the dorsal region continue forward to the occiput. Scales with 22 radiating striae. Myomeres evident, 22 body and 27 caudal $=49$ muscular impressions. Vertebrae, 26 body and 27 caudal $=53$. Color brownish, with many small dark spots about size of pupil, the lighter ground color forming reticulations on the back, some dark shades radiating from the eye and dark bars across lower jaw, dark bars follow the course of the muscular body ridges well down on the flank; belly and fins plain, translucent.

One specimen of this rare fish from the Pacific side of the Isthmus of Panama. Collected by Prof. Manuel Valerio. Length $59 \mathrm{~mm}$. U.S.N.M. no. 101379.

This species is most closely related to $M$. hildebrandi, new species, differing notably in the position of the vent and in fin-ray and myomeric counts.

MICRODESMUS AFFINIS Meek and Hildebrand

Figure 11, $a$; Plate 2, Figure 4

Microdesmus affinis Meek and Hildebrand, Publ. Field Mus. Nat. Hist., zool. ser., vol. 15, pt. 3, pp. 955-6, pl. 98, fig. 1, 1928 (Chame Point, Panama).

Body elongate, of nearly equal depth throughout, somewhat compressed. Lower jaw strongly projecting with a small fleshy lump at the symphysis. Caudal without fin shorter than rest of body; vent midway between occiput and base of caudal fin. Head 10.5 in standard length; depth 16.8 ; predorsal 7.4 ; preanal 1.9 ; caudal 2.1 ; preventral 10.1; base of ventral to vent 2.3 ; snout 5.4 in head, measured to upper end of gill opening; interorbital 7.7. Dorsal 69, anal 43, pectoral 12, ventrals I-3. Eye rather small, high, not fully lateral, the upper rim leaning a little to the median line, 1.7 in snout; mouth small, little oblique, the gape about reaching anterior border of the eye; snout and lower jaw with well-defined longitudinal ridges. Lips thin, with small lateral flanges, the lower of which is slightly the larger; nostrils placed as in related species. Teeth small, close-set in two series in the jaws, none on the palatines or vomer. Gill openings restricted laterally, extending from base of middle pectoral rays obliquely downward and forward to below lower ray of fin, length of the opening about equal to width of pectoral base. Dorsal and anal fins long and low, similar, though the latter much shorter, both fins joined to the caudal at base; origin of dorsal above posterior third of the pectoral length. Body covered with minute scales as in related species, snout and lower jaw naked. Scales with 19 radiating striae. Myomeres evident, 30 body and 33 caudal $=63$ muscular impressions. Vertebrae, 28 body and 34 caudal $=62$. Color uniform olivaceous, fins translucent, caudal slightly darker. 




SCALES OF MICRODESMUS, $\times 80$.

1, M. ionthas (Jordan and Gilbert); 2, M. floridanus (Longley), from the type; 3, M. dipus Günther; 4, M. affinis Meek and Hildebrand, from the type; 5 , M. retropinnis Jordan and Gilbert; 6, M. hildebrandi, new species, from the type; 7, M. intermedius Meek and Hildebrand, from the type; 8, M. multiradiatus Meek and Hildebrand, from the type; 9, M. longipinnis (Weymouth), from a paratype. 

One example $98 \mathrm{~mm}$ in standard length. Collected at Chame Point, Panama, by Robert Tweedlie. U.S.N.M. no. 84300 (type).


FIGURE 11.- a, Microdesmus affinis Meek and Hildebrand, detailed enlargement of head of type, $\times 3$; $b, M$. retropinnis Jordan and Gilbert, detailed enlargement of head, $\times 4 ; c, M$. hildebrandi, new species, detailed enlargement of head of type, $\times 4$.

This species seems most closely related to $M$. longipinnis (Weymouth), agreeing in the number of body and caudal vertebrae as well as fin-ray counts; the difference in position of the vent, as well as proportional measurements, is very pronounced. 


\section{MICRODESMUS RETROPINNIS Jordan and Gilbert}

\section{Figure 9, $e$; Figure 11, $b$; Plate 2, Pigure 5}

Microdesmus retropinnis Jordan and Gilbert, Bull. U. S. Fish Comm., vol. 1, p. 331, 1881 (1882) (Panama).-Jordan and Evermann, U. S. Nat. Mus. Bull. 47, p. 2450, 1898.-Gilbert and Starks, Mem. California Acad. Sci., vol. 4, p. 195, pl. 31, fig. 59, 1904 (Panama).-Meer and Hildebrand, Publ. Field Mus. Nat. Hist., zool. ser., vol. 15, pt. 3, p. 955, 1928 (Panama).

Body moderately elongate, somewhat compressed posteriorly, the caudal portion, without fin, notably shorter than rest of body. Head 11.4 to 13 in standard length; depth 10.5 to 14.4 ; predorsal 3.2 to 3.7 ; preanal 1.3 to 1.8 ; caudal 2.4 to 2.5 ; preventral 11.5 to 12 ; base of ventrals to vent 2 to 2.7 ; snout 4.8 to 5 in head measured to upper end of gill opening; interorbital 5.3 to 6.3 . Dorsal 47 to 49 , anal 30 , pectoral 10, ventral I-3. Eye small, high, lateral; mouth small, little oblique, the gape not quite reaching anterior edge of orbit; lower jaw strongly projecting with a small fleshy prominence at the symphysis; lips with a free flange restricted laterally, the free edge of which does not pass around the mouth anteriorly. Snout and lower jaw with pronounced longitudinal swollen muscular ridges. Anterior nostril in a minute pore at the oral end of the outer frontal ridge; posterior nostril in a small round opening just before and above eye. Teeth comparatively strong, conical, in two irregular series in the jaws; no teeth on the vomer or palatines. Gill openings restricted laterally, adnate to the scapular region in front of the base of the upper fourth pectoral ray, the aperture extending obliquely downward and forward to a point in front of the lower pectoral ray, the openings not so long as the width of the base of the fin. Body and head, except snout and lower jaw, covered with minute nonimbricate scales imbedded in the skin; at the base of the vertical fins on either side of the median line of the back the arrangement of the rows of scales is notably differentiated in that the rows diverge outward and backward following the direction of the myomeric impressions. Scales with 39 radiating striae. Myomeres evident, 31 body and 26 caudal $=57$ muscular impressions. Vertebrae, 32 body and 25 caudal $=57$.

Origin of the dorsal fin more than two head-lengths behind the head, or opposite a point midway between tip of lower jaw and the vent, or a little nearer the former. Dorsal and anal fins long and low, similar, but the anal much shorter, both fins joined to the caudal by membrane. Ventrals very small, closely approximated and situated slightly behind the base of the pectorals. Color brownish above slightly paler below, upper part of sides with two longitudinal rows of quadrate dark-brown spots; the upper series united over median line of back and separated from the succeeding ones by light interspaces of the ground color, forming faint cross bars on the predorsal region, 
shades of the upper row faintly invading the membrane of the base of the dorsal fin; sides of the head and lower jaw indefinitely shaded with brownish.

Two specimens, 80 and $91 \mathrm{~mm}$ in standard length; the smaller from a tide pool at Panama. Collected March 21, 1912, by Meek and Hildebrand. U.S.N.M. no. 82678. The larger example, no. 82705, collected at Chame Point, Panama, by Robert Tweedlie.

Distinguished from all other species of the genus by the much greater posterior insertion of the dorsal fin.

\section{MICRODESMUS HILDEBRANDI, new species}

Figure 9, f; Figure 11, c; Plate 2, Figure 6

Microdesmus dipus (not Günther) Meek and Hilderrand, Publ. Field Mus. Nat. Hist., zool. ser., vol. 15, pt. 3, pp. 956-957, 1928 (Panama).

Body elongate, comprassed posteriorly; tail notably longer than rest of body, its length to base of caudal fin 1.7 in total length. Head short, 10.6 in standard length. Depth 20; predorsal 6.3; preanal 2.1; preventral 10.2; ventral to vent 2.7 ; snout 4.9 in head measured to upper angle of gill opening. Dorsal 55, anal 38, pectoral 10, ventral I-3. Eye small, lateral, high. Interorbital rather broad, the space between the eyes 3.7 in head. Mouth small, little oblique, reaching about to anterior edge of the eye. Lower jaw strongly projecting; lips fleshy, with pronounced lateral flanges, the free margin of which is confined to the side of the head. The frontal region and lower jaw with pronounced longitudinal swollen muscular folds or ridges; the former extending from interorbital region to tip of snout; the latter from tip of lower jaw to posterior end of mandible. Anterior nostril situated in a minute round pore at the oral end of the frontal ridges; posterior nostril slightly larger and situated above and before the eye. Teeth small, even, close-set, in two irregular series in the jaws; vomer and palatines toothless. Gill openings restricted laterally, extending from base of the middle pectoral rays obliquely downward and forward to slightly below and before the lower pectoral ray, the apertures slightly longer than width of the base of pectoral fin. Body and head, except snout and lower jaw, covered with minute scales imbedded in the skin; at the base of the dorsal and anal fins the arrangement of the scales is notably differentiated in that they are imbedded in oblique rows extending outward and backward on a longitudinal narrow flat plane extending the full length of the fin bases. Scales with 24 radiating striae. Myomeres evident, 20 body and 31 caudal $=$ 51 muscular impressions. Vertebrae, 19 body and 37 caudal $=56$. Vertical fins long and low, confluent with the caudal fin at base. Origin of dorsal fin above tip of pectoral. Anal similar to but shorter 
than dorsal. Ventral fins small, very close together and situated slightly behind base of pectorals. Vent preceded by longitudinal striations of the skin of the belly, indicating that the region is capable of some distension. Color olivaceous, fins plain, translucent, the caudal dark brown.

A single example $104 \mathrm{~mm}$ in standard length; taken at Chame Point, Panama, by Robert Tweedlie. U.S.N.M. no. 86547 (type).

This species is closely related to $M$. dipus Günther but differs greatly in the position of the vent, fin-ray, and myomeric counts.

I take great pleasure in dedicating this species to Dr. Samuel F. Hildebrand, ichthyologist, United States Bureau of Fisheries, in recognition of his valuable work on the fishes of Panama.

\section{MICRODESMUS INTERMEDIUS Meek and Hildebrand}

\section{Figure 12, $a$; Plate 2, Figure 7}

Microdesmus intermedius Meen and Hildebrand, Publ. Field Mus. Nat. Hist., zool. ser., vol. 15, pt. 3, p. 957-958, fig. 2, 1928 (Panama).

Body elongate, compressed, the caudal portion, without fin, notably longer than rest of body. The body of about equal depth throughout. Head 8 to 8.4 in standard length; depth 10.3 to 13.3 ; predorsal 5.6 to 6.4 ; preanal 2.1 to 2.5 ; caudal 1.4 to 1.6 ; preventral 8 to 9.7 ; base of ventrals to vent 3 to 3.6 . Snout 5 in head, measured to upper end of gill opening; interorbital 5 to 5.5. Dorsal 67, anal 48, pectoral 12, ventral I-3. Myomeres evident, 17 body and 34 caudal $=51$ muscular impressions. Vertebrae, 22 body and 33 caudal $=55$. Eye minute, high, about 3 in length of snout. Mouth comparatively large, the gape oblique, reaching to slightly past anterior edge of orbit. Lower jaw somewhat projecting, but less so than in related species, the fleshy projection at the symphysis little developed; lips with conspicuous free flanges restricted to the side of the jaws and not forming a free fold anteriorly. Snout and lower jaw with longitudinal grooves and ridges, the latter extending well back under the branchial region. Anterior nostril in a minute pore at the oral end of the frontal ridges; posterior nares in a small round opening above and before eyes. Teeth small, close-set, conical, apparently in two irregular series in the jaws; vomer and palatines toothless. Gill openings restricted laterally, the upper end adnate to the scapular region in front of the middle pectoral rays, the apertures extending obliquely downward and forward to a point slightly below the base of the lower pectoral ray, the opening not quite so long as the width of the fin base. Pores of the head rather small, five short vertical rows below the eye, two horizontal rows behind and below eye crossed by two vertical rows on the temporal region. A faint cross is formed by rows of minute pores on the cheek, the juncture of which is about 



Figure 12.-a, Microdesmus intermedius Meek and Hildebrand, detailed enlargement of head of type, $\times 3 ; b, M$. multiradiatus Meek and Hildebrand, detailed enlargement of head of type, $\times 21 / 2 ; c, M$. longipinnis (Weymouth), detailed enlargement of head of paratype, $\times 3$. 
midway between the eye and the lower angle of the preopercle. Body and head, except snout and lower jaw, covered with minute nonimbricate scales imbedded in the skin; scales of the dorsal region following the course of the upper branches of the myomeric impressions. Scales with 31 radiating striae. Origin of the dorsal fin opposite, or a little before tip of appressed pectoral; the fin long and low, joined to the caudal at base by membrane. Ventrals small, closely approximated, situated below the branchial openings. Color uniform pale olivaceous; the caudal fin dusky; other fins plain, translucent.

This species is represented by the type, $84 \mathrm{~mm}$ in standard length, U.S.N.M. no. 84301, collected at Chame Point, Panama, by Robert Tweedlie, and two paratypes, no. 82680,68 and $96 \mathrm{~mm}$, respectively, from the same locality, taken March 8-14, 1913, by Mr. Tweedlie.

This species is close to $M$. affinis Meek and Hildebrand and $M$. longipinnis (Weymouth) but differs in the position of the vent, fewer body vertebrae, and proportional measurements.

MICRODESMUS MULTIRADIATUS Meek and Hildebrand

Figure 12, $b$; Plate 2, Figure 8

Microdesmus multiradiatus Meek and Hildebrand, Publ. Field Mus. Nat. Hist., zool. ser., vol. 15, no. 249, p. 958, pl. 98, fig. 3, 1928 (Panama).

Body very elongate, eel-shaped, the caudal notably longer than rest of body. Head 9.7 to 12.8 in standard length; depth 20.2 to 28.0 ; predorsal 6.6 to 8.5 ; preanal 2.4 to 2.7 ; caudal without fin 1.6 to 1.7 ; preventral 9.7 to 11.6 ; base of ventrals to vent 3.2 to 3.6 . Snout 4.0 to 6.0 in length of head, measured from tip of lower jaw to upper end of gill openings; interorbital 3.2 to 6.1. Dorsal 73 to 78 , anal 57 to 61 , pectoral 12 , ventral I-3. Eye small, high, superlateral; mouth comparatively large, little oblique, the maxillary to anterior edge of eye. Lower jaw projecting with a small inconspicuous fleshy tip. Lips very large, restricted laterally, the free flange above and below very conspicuous, the two membranes joined together around the posterior end of the gape; the free folds of the lips do not extend around the mouth anteriorly. Snout and lower jaw with pronounced longitudinal swollen muscular ridges, those of the lower jaw extending well back under the mandible. Anterior nostril in a minute porelike opening at the oral end of the outer frontal ridges. Posterior nostril in a small round opening on the frontal ridge before and in front of the eye. Muscles of the jaws well developed, the cheeks somewhat tumid. Teeth comparatively strong, in two irregular series in the jaws, the lower jaw with three or four small canines in the outer series, vomer and palatines toothless. Gill openings restricted laterally, adnate to the scapular region in front of the base of the upper fourth pectoral ray, the aperture extending 


\section{$2 \mathrm{BHL}$ Biodiversity Heritage Library}

Reid, Earl D. 1936. "Revision of the fishes of the family Microdesmidae, with description of a new species." Proceedings of the United States National Museum 84(3002), 55-72. https://doi.org/10.5479/si.00963801.84-3002.55.

View This Item Online: https://www.biodiversitylibrary.org/item/32837

DOI: https://doi.org/10.5479/si.00963801.84-3002.55

Permalink: https://www.biodiversitylibrary.org/partpdf/4210

\section{Holding Institution}

Smithsonian Libraries

\section{Sponsored by}

Smithsonian

\section{Copyright \& Reuse}

Copyright Status: NOT_IN_COPYRIGHT

Rights: https://www.biodiversitylibrary.org/permissions/

This document was created from content at the Biodiversity Heritage Library, the world's largest open access digital library for biodiversity literature and archives. Visit BHL at https://www.biodiversitylibrary.org. 